(c) American Dairy Science Association, 2003.

\title{
Effects of Body Surface Area Estimates on Predicted Energy Requirements and Heat Stress
}

\author{
A. Berman \\ Department of Animal Science, Hebrew University, Rehovot 76100, Israel
}

\begin{abstract}
The $0.09 \times \mathrm{W}^{0.67}$ equation (where $\mathrm{W}=$ weight in kilograms) used to estimate body surface area (SA) in cattle energy requirements models was developed using measurements of sheep that weighed between 24 and $38 \mathrm{~kg}$. The SA estimates it produced were compared with those of the equation $0.14 \times \mathrm{W}^{0.57}$, based on Holstein cattle weighing 41 to $617 \mathrm{~kg}$. The estimate of SA produced by the first equation was $23 \%$ greater for a $650-\mathrm{kg}$ cow than that obtained by the second equation. The impact of SA estimates on thermal comfort range and development of cold and heat stress effects was calculated, using a thermal balance model, for a $600-\mathrm{kg}$ cow producing $35 \mathrm{~kg} / \mathrm{d}$. Predicted metabolic heat production increment at $-10^{\circ} \mathrm{C}$ ambient temperature with $0.5 \mathrm{~m} / \mathrm{s}$ wind velocity was $0.44 \mathrm{Mcal} / \mathrm{d}$ and $1.21 \mathrm{Mcal} / \mathrm{d}$ by the first and second equation, respectively. Predicted lower critical temperature (LCT) was $-8.7^{\circ} \mathrm{C}$ by the first equation and $-0.6^{\circ} \mathrm{C}$ by the second equation, an $8^{\circ} \mathrm{C}$ difference. The LCT difference between SA estimates increased from 4.6 to $9.4^{\circ} \mathrm{C}$, with milk production rising from 10 to $45 \mathrm{~kg} /$ d. By the first equation, skin nonevaporative heat loss started to decrease at $15^{\circ} \mathrm{C}$ and became close to nil at and ambient temperature of $35^{\circ} \mathrm{C}$, whereas by the second equation, respective values were $10^{\circ} \mathrm{C}$ and $39^{\circ} \mathrm{C}$, a $5^{\circ} \mathrm{C}$ shift in the estimated temperature at which thermal stress would start developing. The larger SA and skin water loss predicted by the first equation reduced by $50 \%$ the respiratory heat loss involved in maintenance of thermal balance at higher temperatures for a $600-\mathrm{kg}$ cow. The second equation seems preferable for Holstein SA estimation since it is based on Holstein cattle data. It provides more adequate estimates of energy requirement in the cold and of heat stress relief needs for Holstein cattle.
\end{abstract}

(Key words: body surface, energy requirements, heat stress, thermal comfort)

Abbreviation key: CNCPS = Cornell Net Carbohydrate and Protein System, $\mathbf{H}_{\mathbf{c r}}=$ combined convective

Received March 18, 2003.

Accepted June 18, 2003.

E-mail: berman@agri.huji.ac.il. and radiant heat loss, $\mathbf{H P}=$ metabolic heat production, INS = total body insulation, $\mathbf{L C T}=$ lower critical temperature, $\mathbf{S A}$ = body surface area.

\section{INTRODUCTION}

The exchange of heat between animal and environment is a major component of metabolic heat production, in addition to growth, milk production, pregnancy, and activity components. The surface area (SA) of the animal is the interphase for skin convective, radiant, and evaporative heat loss, complemented by convective and evaporative heat loss via the respiratory system. The SA is a component of thermal exchange models (McGovern and Bruce, 2000; Turnpenny et al., 2000; Gebremehdin and $\mathrm{Wu}, 2001$ ) and used in models of energy requirements (ARC, NRC, CNCPS) for the computation of energy requirements during cold and heat stress conditions. The estimate of SA is valuable for the estimation of energy requirements in the cold as well as that of heat stress at higher ambient temperatures.

The capacity for controlling animal environments has markedly increased in the last decades. The development of heat stress relief methods by forced ventilationenhanced evaporation creates the option of using automated systems for relief of heat stress. The implementation of such an option requires estimates of the lower and upper critical temperatures (the lower limit of the thermal comfort range), as well as the rate of development of cold and heat stress at ambient temperatures that deviate from the lower critical temperature. The equations that produce these estimates comprise as crucial elements values of SA, thermal insulation, and metabolic heat production.

The SA of an animal can be estimated either by direct measurement or by a predictive equation. The relationships between body mass and SA area had been examined since mid-19th century. They were apparently pioneered by Meeh (1879; cited by Lusk, 1928), who proposed the Euclidian theorem that for bodies of similar shape, surface area is proportional to the two-thirds power of their volume: $\mathrm{a} \times \mathrm{W}^{0.67}$. This proposition was followed by extensive studies in the late-19th century and the first half of the 20th century, as reviewed by Brody (1945), Kleiber (1961), and Mitchell (1962). These 
studies resulted in the formulation of predictive equations relating SA to body mass. Some of the equations presume similarity of body proportions with increasing body mass, and others are empirical.

Equations that presume similarity of body proportions also imply that body shape, as well as body mass density, remain similar with increasing body mass. These equations share the "0.67" exponent for body mass but may differ in the proportionality factor "a." Such equations were proposed by Meeh (1879), as cited by Lusk (1928) and Mitchell (1928). In the study carried out by Meeh in 1879 on calves of unspecified breed and age, the factor was 0.105 . In the study of Mitchell (1928), a 0.085 factor was derived from measurements of 14 sheared sheep, weighing 24 to $38 \mathrm{~kg}$, varying in body condition. This factor was reduced to 0.09 and used in studies of heat exchange of sheep and steers at the Hannah Dairy Research Institute in Scotland (Graham et al., 1959; Blaxter and Wainman, 1961), and then for estimating energy requirements in a British Agricultural Research Council (ARC) publication (1980). This equation was later used in the NRC Nutrient Requirements of Beef Cattle (1996) and Dairy Cattle (2001) models, in a model of environmental effects on the nutrient requirements of dairy cattle (Fox and Tylutki, 1998) in the Cornell Net Carbohydrate and Protein System (CNCPS; Fox et al., 2000), and in two thermal exchange models for mature dairy cows (McGovern and Bruce, 2000; Turnpenny et al., 2000).

Within a species, body mass increases during growth and aging. The increase in BW is associated with changes in proportion of body parts, mainly in relative reduction of body appendages (Brody, 1945), which would reduce surface area per unit of BW. This feature of growth and aging may add accuracy to equations based on direct measurements of surface area of animals of different BW within a species. Hence, the accuracy of SA prediction might be improved by using equations of the $\mathrm{a} \times \mathrm{W}^{\mathrm{b}}$ form, where $\mathrm{W}=$ weight in kilograms, with no presumptions on the values of either the "a" factor or the "b" exponent. Two studies of SA in Holstein cattle adopted the empirical approach. The SA was measured by a surface integrator (Brody, 1945) and was related to BW using exponential equations. The measurements were carried out in one study on 50 animals from birth to maturity with BW ranging from 41 to $617 \mathrm{~kg}$ (Brody, 1945), and in the other on six animals with BW ranging from 68 to $317 \mathrm{~kg}$ (Johnson et al., 1961). The two studies produced different equations, $0.14 \times \mathrm{W}^{0.57}$ and $0.235 \times$ $\mathrm{W}^{0.46}$, respectively. The first equation was used in a thermal balance model (Gebremehdin and $\mathrm{Wu}, 2002$ ).

This study examined the SA estimated by these equations, the experimental evidence validating these equations for Holstein cows, and their effects on estimates of the lower critical temperature (LCT) and on the prediction of cold and heat stress development at ambient temperatures below and above the LCT.

\section{MATERIALS AND METHODS}

The SA was calculated according to four equations: $0.105 \times \mathrm{W}^{0.67}$ (Meeh, 1879), $0.09 \times \mathrm{W}^{0.67}$ (Mitchell, 1928), $0.14 \times \mathrm{W}^{0.57}$ (Brody, 1945), $0.235 \times \mathrm{W}^{0.46}$ (Johnson et al., 1961), for animals ranging in BW from 25 to $650 \mathrm{~kg}$, to assess their impact on SA estimates.

The effects of SA estimates on heat exchange were calculated using a model for the thermal balance of cattle (McGovern and Bruce, 2000). The model is based on physical characteristics of heat exchange between the animal and its environment, as well as on published data on thermoregulatory responses of cattle. Given data on characteristics of the animal (BW, metabolic heat production, skin evaporation capacity, and hair coat depth) and of the environment (temperature, humidity, radiation, and air velocity), the model can be used to calculate and present as output animal responses (e.g. respiratory heat loss, skin evaporative and nonevaporative heat loss, and rate of body temperature change). The effects of SA on heat exchange were estimated for a $600-\mathrm{kg}$ cow producing $35 \mathrm{~kg} / \mathrm{d}$ of $3.5 \%$ fat milk, with a maximal capacity of skin water evaporation of $300 \mathrm{~g} /$ $\mathrm{m}^{2} \mathrm{~h}$, having a 5-mm-thick hair coat, and exposed to a $1 \mathrm{~m} / \mathrm{s}$ air velocity at ambient temperatures from 10 to $40^{\circ} \mathrm{C}$ (by $5^{\circ} \mathrm{C}$ steps), at $20 \%$ relative humidity, and radiant temperature equal to air temperature. An air velocity of $1 \mathrm{~m} / \mathrm{s}$ was used in these calculations, to reduce the limitation of skin heat loss by boundary layer effects in the air surrounding the animal. The low relative humidity was chosen to avoid ambient humidity restrictions on skin and respiratory evaporative heat loss. The assumption made in the model that air is expired at deep body temperature was replaced by an empirical equation based on experimental data (Stevens, 1981). Respiratory frequencies in field studies (Berman, 1971) were highly correlated $(r=0.996)$ with those predicted by equations used by Stevens (1981) in his estimates of respiratory water loss.

Heat is lost from the animal by evaporative heat loss and by non-evaporative heat loss. The evaporative heat loss, from the respiratory tract and from the skin, is relative (but not linearly proportional) to heat stored in the body. In contrast, the non-evaporative heat loss is determined by the animal-to-environment temperature gradient and by the surface of the animal. As such, nonevaporative heat loss is an appropriate parameter for effects of SA on thermal balance. It is estimated by the sum of convective heat loss and radiant skin heat loss 
$\left(\mathbf{H}_{\text {cr }}, \operatorname{Mcal}\left(\operatorname{cow}^{-1} \cdot \mathrm{d}^{-1}\right)\right.$. The $\mathrm{H}_{\mathrm{cr}}$ is expressed in equation form by:

$$
\mathrm{H}_{\text {cr }}=\mathrm{SA}\left[\alpha \bigvee_{\mathrm{v}}\left(\mathrm{T}_{\mathrm{s}}-\mathrm{T}_{\mathrm{a}}\right)+\beta_{1}\left(\beta_{\mathrm{e}}^{\circ} \mathrm{K}_{\mathrm{e}}^{4}-\beta_{\mathrm{s}}^{\circ} \mathrm{K}_{\mathrm{s}}^{4}\right)\right]
$$

where $\alpha=$ convective heat constant; $\mathrm{v}=$ air velocity $(\mathrm{m} /$ $\mathrm{s}) ; \mathrm{T}_{\mathrm{s}}=$ animal surface temperature $\left({ }^{\circ} \mathrm{C}\right) ; \mathrm{T}_{\mathrm{a}}=$ air temperature $\left({ }^{\circ} \mathrm{C}\right) ; \beta_{1}=$ Stefan-Boltzmann radiation constant; $\beta_{\mathrm{e}}$ and $\beta_{\mathrm{s}}=$ emissivities of the environment and body surface, respectively; ${ }^{\circ} \mathrm{K}_{\mathrm{e}}$ and ${ }^{\circ} \mathrm{K}_{\mathrm{s}}=$ absolute temperatures of the environment and body surface, respectively.

The $\mathrm{H}_{\text {cr }}$ was obtained from thermal balance model outputs at the afore-mentioned ambient temperatures with SA calculated by either the $0.09 \times \mathrm{W}^{0.67}$ (Mitchell, 1928 ) or the $0.14 \times \mathrm{W}^{0.57}$ (Brody, 1945) equations.

The LCT estimates the ambient temperatures at which minimal metabolic heat production (HP) equals heat loss. At ambient temperatures below LCT, energy maintenance cost gradually increases, and at ambient temperatures above it, heat stress progressively develops. The LCT is estimated by the following equation (NRC, 2001):

$$
\mathrm{LCT}=39-(\mathrm{INS} \times \mathrm{HP} \times 0.85)
$$

where LCT $=$ lower critical temperature; INS $=$ tissue insulation + external insulation $\left({ }^{\circ} \mathrm{C} /\left[\mathrm{m}^{2} \cdot \mathrm{d} \cdot \mathrm{Mcal}\right]\right) ; \mathrm{HP}=$ metabolic heat production $\left(\mathrm{Mcal} /\left[\mathrm{m}^{2} \cdot \mathrm{d}\right]\right) ; 0.85=$ proportion of metabolic heat production lost via the skin.

Heat production at different milk yields was calculated according to NRC (2001): maintenance heat production as $0.080 \mathrm{Mcal} / \mathrm{kg} \mathrm{BW}^{0.75}$, milk $\mathrm{NE}_{\mathrm{L}}$ concentration $=0.36+[0.0969($ fat\% $)]$, efficiency of dietary ME for milk energy production as $64 \%$. Tissue insulation and external insulation were calculated according to NRC (2001) equations for a cow weighing $600 \mathrm{~kg}$, with a BCS of 4.5 (on a 1 to 9 scale), exposed to an environment in which air velocity is $0.5 \mathrm{~m} / \mathrm{s}$ and clean hair coat is $0.63 \mathrm{~cm}$ thick. Total insulation values were 12.8 and $15.3^{\circ} \mathrm{C} /$ $\left(\mathrm{m}^{2} \cdot \mathrm{d} \cdot \mathrm{Mcal}\right)$ for the $0.09 \times \mathrm{W}^{0.67}$ (Mitchell, 1928) and $0.14 \times \mathrm{W}^{0.57}$ (Brody, 1945) equations for estimation of SA, respectively.

\section{RESULTS}

\section{Body Surface Estimates}

The SA calculated according to the four equations for animals ranging in BW from 25 to $650 \mathrm{~kg}$ (Figure 1) indicate that estimates of SA are similar for BW under $100 \mathrm{~kg}$. They progressively diverge, however, with increasing BW. The SA calculated by the $0.105 \times \mathrm{W}^{0.67}$ equation (Meeh, 1879) leads to SA estimates markedly higher than those obtained by the other equations. For

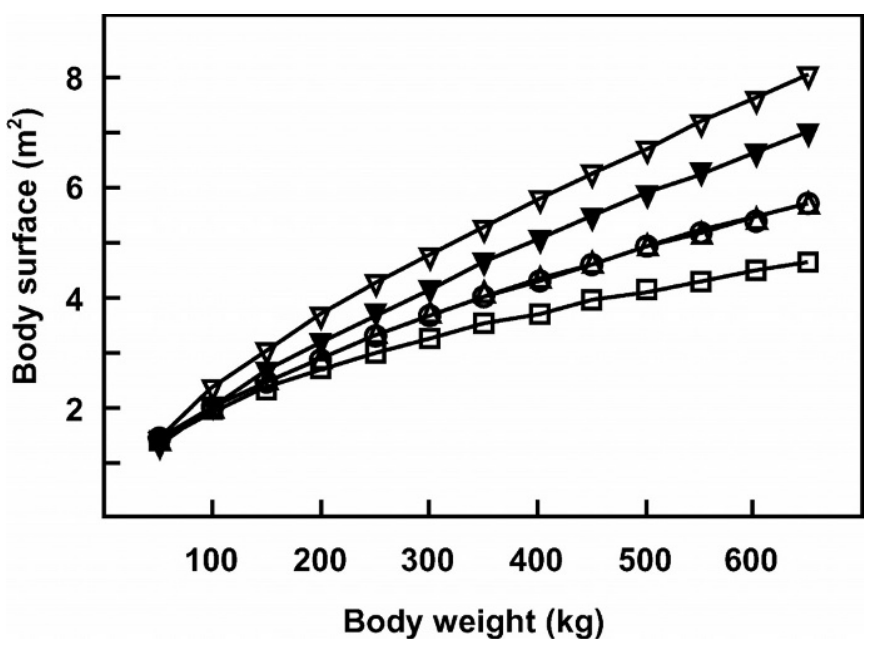

Figure 1. Relationship between BW and body surface area calculated using the different equations: $-0.105 \times \mathrm{W}^{0.67}(\nabla ;$ Meeh, 1879), $-0.09 \times \mathrm{W}^{0.67}\left(\triangle\right.$; Mitchell, 1928), $-0.14 \times \mathrm{W}^{0.57}(\mathbf{\Delta} ;$ Brody, 1945), $-0.235 \times \mathrm{W}^{0.46}$ ( $\square$; Johnson et al., 1961), where $\mathrm{W}=$ weight in kilograms.

a cow of $600 \mathrm{~kg}$ of BW, it is $14 \%$ higher than the estimate obtained by the equation $0.09 \times \mathrm{W}^{0.67}$ (Mitchell, 1928), $30 \%$ higher than the estimate obtained by the equation $0.14 \times \mathrm{W}^{0.57}$ (Brody, 1945), and $42 \%$ higher than the estimate based on growing calves (Johnson et al., 1961).

The SA calculated by the $0.09 \times \mathrm{W}^{0.67}$ equation (Mitchell, 1928) departs considerably from that obtained by using the empirical $0.14 \times \mathrm{W}^{0.57}$ equation (Brody, 1945). For a $30-\mathrm{kg}$ animal, close to mean BW of the sheep in Mitchell's study (Mitchell, 1928), the predicted SA is $90 \%$ of that predicted by Brody's equation. For a $40-\mathrm{kg}$ animal, the birth weight of Holstein calves, the estimated SA is $93 \%$ of that calculated by Brody's equation. The two curves converge at a BW of about $75 \mathrm{~kg}$. At higher BW, the SA calculated by Mitchell's equation gradually increases relative to that calculated by Brody's equation, to reach $123 \%$ of the latter at a BW of $650 \mathrm{~kg}$, the weight of a mature Holstein cow.

The $0.235 \times \mathrm{W}^{0.46}$ equation determined on growing Holstein calves (Johnson et al., 1961) produces SA estimates similar to those of Brody's equation at BW less than $200 \mathrm{~kg}$, but are increasingly smaller at higher BW. At a BW of $650 \mathrm{~kg}$, the predicted SA is $82 \%$ of that calculated by Brody's equation.

A larger relative SA estimate results in the reduction of calculated metabolic heat production per unit of SA. It also produces a larger surface for convective and radiant exchange, as well as greater skin evaporative heat loss. Therefore, difference in estimates of SA may affect the predicted responses to environmental conditions. 


\section{Lower Critical Temperatures}

By its definition, LCT varies with the estimates for total insulation (INS), as well as with HP (i.e., level of milk production). Both HP and insulation are expressed as heat fluxes per unit of SA. They are therefore both affected by the estimate of SA. At constant HP, an increase in SA would reduce HP, expressed as $\mathrm{Mcal} /\left(\mathrm{m}^{2} \cdot \mathrm{d}\right)$, and increase the numerical value of INS, expressed as ${ }^{\circ} \mathrm{C} /\left(\mathrm{m}^{2} \cdot \mathrm{d} \cdot \mathrm{Mcal}\right)$. The rate at which energy requirements rise when ambient temperatures decline below the LCT is determined by the INS. Below the LCT, tissue insulation may be expected to be maximal and constant, as long as it is not fluctuating due to cold-induced vasodilatation. Hence, external insulation and SA predominantly determine the rate of increase in energy requirements at ambient temperatures below the LCT. At ambient temperatures above the LCT, the rate at which nonevaporative heat loss decreases is also determined by the same factors, as well as by tissue insulation that gradually decreases down to its minimal value. Larger SA and/or smaller insulation therefore imply higher rates of energy requirement increases at ambient temperatures below the LCT, and a narrower thermal comfort range. At ambient temperatures above the LCT, these imply an earlier onset of heat stress and its faster development. Therefore, the implications of using either Mitchell's or Brody's equation were to be examined.

The LCT was calculated for a cow weighing $600 \mathrm{~kg}$ and producing $35 \mathrm{~kg}$ of $3.5 \%$ fat milk. Its HP was 3.66 $\mathrm{Mcal} /\left(\mathrm{m}^{2} \cdot \mathrm{d}\right)$ if SA were calculated according to the equation of Mitchell (1928) and $4.37 \mathrm{Mcal} /\left(\mathrm{m}^{2} \cdot \mathrm{d}\right)$ if it was calculated according to that of Brody (1945). Predicted LCT was $-0.6^{\circ} \mathrm{C}$ when using Brody's estimate for SA, and $-8.7^{\circ} \mathrm{C}$ when Mitchell's estimate was used (i.e., an $8^{\circ} \mathrm{C}$ difference in LCT between the two estimates of SA).

\section{Metabolic Rate Below LCT}

Insulation values also are affected by the estimate of SA. Total insulation values were 12.8 and $15.3^{\circ} \mathrm{C} /$ $\left(\mathrm{m}^{2} \cdot \mathrm{d}(\mathrm{Mcal})\right.$ for the $0.09 \times \mathrm{W}^{0.67}$ (Mitchell, 1928) and $0.14 \times \mathrm{W}^{0.57}$ (Brody, 1945) equations, respectively. These insulation values were used for the calculation of the rise in HP expected to occur when ambient temperatures decrease below the LCT. The rate of rise in HP was $18 \%$ smaller by Mitchell's equation than by Brody's equation for SA (Figure 2). The two SA equations produced not only different LCT estimates, but also different rates of rise in heat production below the LCT. As a result of these two effects, the difference in predicted heat production between the two SA estimates gradually increased with declining ambient temperatures. At $-15^{\circ} \mathrm{C}$ ambient temperature and $0.5 \mathrm{~m} / \mathrm{s}$ wind velocity, the predicted

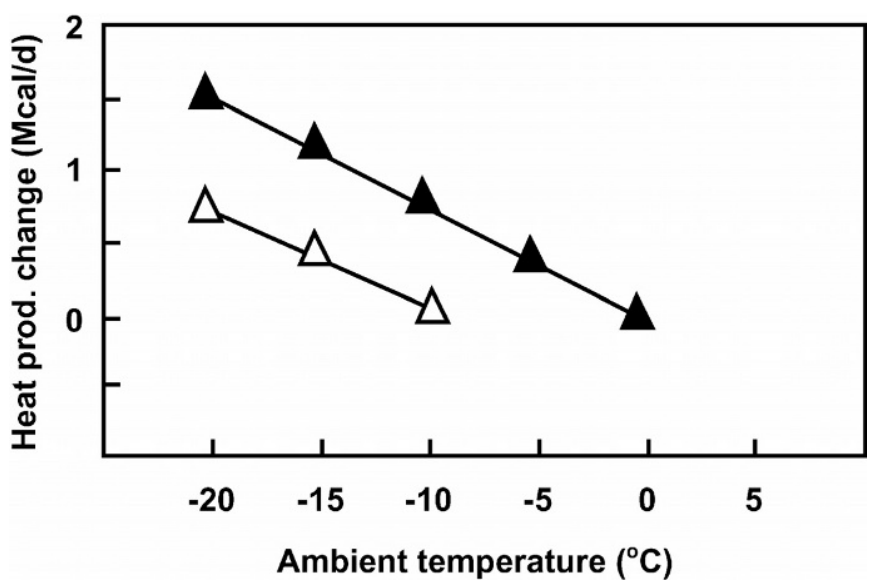

Figure 2. Increments in predicted metabolic heat production at ambient temperatures below the lower critical temperatures if body surface area is estimated according to $\mathrm{SA}=0.09 \times \mathrm{W}^{0.67}(\triangle$; Mitchell, $1928)$, or to $\mathrm{SA}=0.14 \times \mathrm{W}^{0.57}(\boldsymbol{\Lambda} ;$ Brody, 1945), where $\mathrm{W}=$ weight in kilograms.

increment in HP was $0.44 \mathrm{Mcal} / \mathrm{d}$ by Mitchell's estimate and $1.21 \mathrm{Mcal} / \mathrm{d}$ by Brody's estimate.

\section{Milk Production Effect on LCT}

Higher milk production is associated with higher HP, which by itself would shift LCT to lower ambient temperatures. The shift in LCT would differ with the SA estimates, as these modify the insulation terms. The LCT declined with rising milk production (Figure 3 ). The two estimates of SA produced significant differences in the decline of LCT with rising milk production. The difference in LCT between the two estimates increased two-

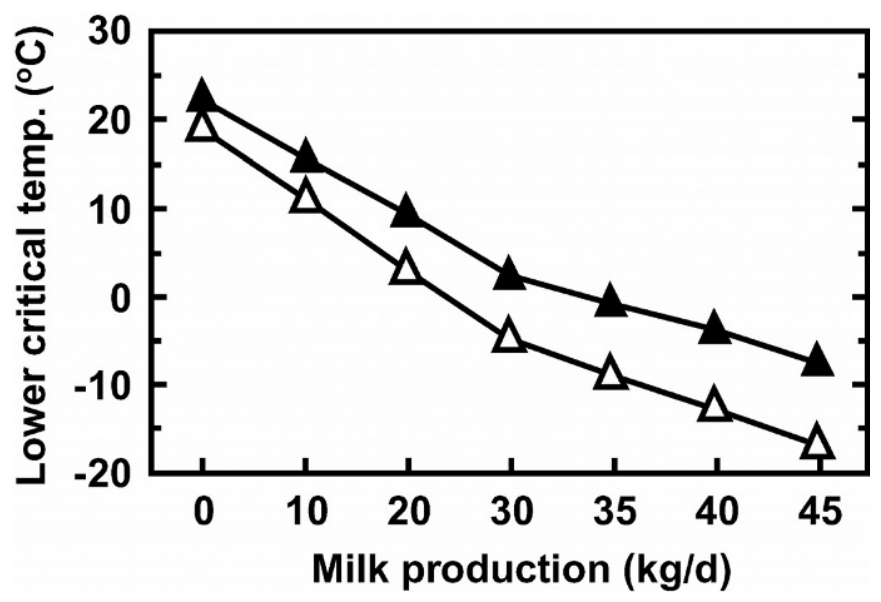

Figure 3. Relationship of predicted lower critical temperatures to daily milk production if body surface area is estimated according to $\mathrm{SA}=0.09 \times \mathrm{W}^{0.67}(\triangle$; Mitchell, 1928$)$, or to $\mathrm{SA}=0.14 \times \mathrm{W}^{0.57}(\boldsymbol{\triangle}$; Brody, 1945), where $\mathrm{W}=$ weight in kilograms. 


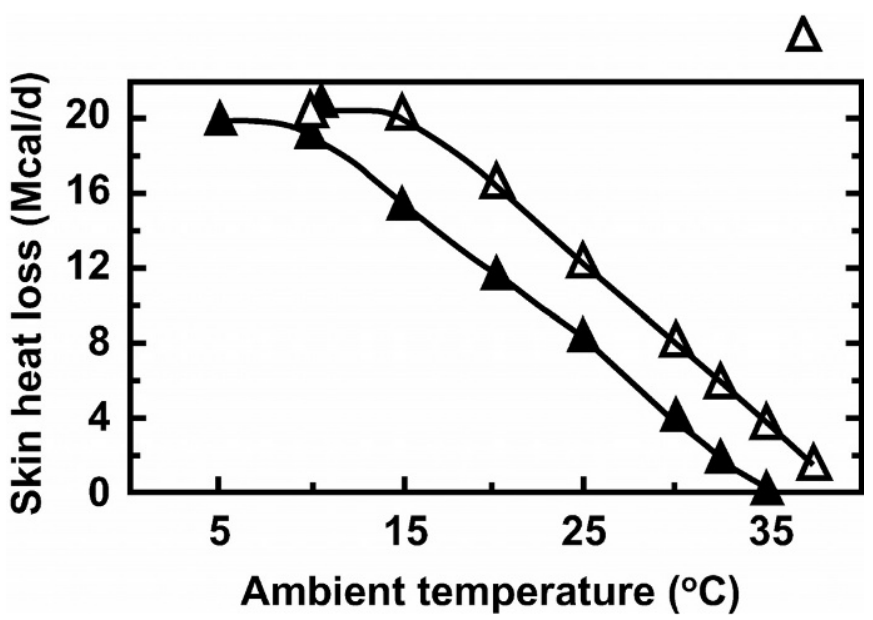

Figure 4. Relationship of total predicted nonevaporative skin heat loss at different ambient temperatures if body surface area is estimated according to $\mathrm{SA}=0.09 \times \mathrm{W}^{0.67}(\triangle$; Mitchell, 1928), or to $\mathrm{SA}=$ $0.14 \times \mathrm{W}^{0.57}(\mathbf{\Lambda} ;$ Brody, 1945), where $\mathrm{W}=$ weight in kilograms.

fold, from 4.6 to $9.4^{\circ} \mathrm{C}$, with milk production rising from 10 to $45 \mathrm{~kg} / \mathrm{d}$.

\section{Heat Stress Estimate}

The impact of a larger $\mathrm{SA}$ on $\mathrm{H}_{\mathrm{cr}}$ was calculated using the thermal balance model (McGovern and Bruce, 2000). By Brody's surface area estimate, total $\mathrm{H}_{\mathrm{cr}}$ started to decrease at $10^{\circ} \mathrm{C}$ and became close to nil at $39^{\circ} \mathrm{C}$ ambient temperatures. By Mitchell's body surface estimate, $\mathrm{H}_{\text {cr }}$ started to decrease at $15^{\circ} \mathrm{C}$ and became close to nil at $35^{\circ} \mathrm{C}$. The difference in $\mathrm{H}_{\mathrm{cr}}$ between the two estimates remained constant between 15 and $35^{\circ} \mathrm{C}$ (Figure 4). Using Mitchell's estimate instead of Brody's estimate for SA had the effect of increasing by $5^{\circ} \mathrm{C}$ the temperature at which $\mathrm{H}_{\mathrm{cr}}$ starts to decrease with rising ambient temperatures. This represents a $5^{\circ} \mathrm{C}$ shift in the estimated ambient temperature at which thermal stress would start to develop.

A decrease in $\mathrm{H}_{\text {cr }}$ with rising ambient temperatures is associated with recruitment of evaporative heat loss from the skin and the respiratory tract. Adopting Mitchell's larger SA estimate increases the predicted total skin evaporative heat loss, but does not affect the estimated capacity for respiratory evaporative heat loss. It presumes a $23 \%$ larger SA for a $600-\mathrm{kg}$ cow, which reduces by about $50 \%$ the part of respiratory heat loss in maintenance of thermal balance at higher ambient temperatures. According to it, markedly lower respiratory frequencies are to be expected in animals exposed to heat. The presumption of a $23 \%$ larger SA also increased by about $2{ }^{\circ} \mathrm{C}$ the ambient temperature at which body temperatures would start rising.

\section{DISCUSSION}

The equation suggested by Mitchell (1928), was applied to animals of increasing BW, up to 20 times that of the 27- to $34-\mathrm{kg}$ sheep on which it was originally determined. It was used by British and Canadian researchers from 1959 onward in studies of energy metabolism in sheep weighing 50 to $60 \mathrm{~kg}$ (Graham et al., 1959), in heifers weighing 150 to $300 \mathrm{~kg}$ (Webster et al., 1970), in steers weighing 320 to $520 \mathrm{~kg}$ (Blaxter and Wainman, 1961; 1964), and in beef cows weighing 500 to $570 \mathrm{~kg}$ (Young, 1975). The values derived form the latter studies were subsequently used for the prediction of energy requirements in the cold for cattle (Blaxter, 1967; NRC, 1981), later for predicting beef cattle energy requirements (NRC, 1996), and later still for nutritional requirements models for dairy cattle (CNCPS, 2000; NRC, 2001).

Mitchell's equation overestimates the SA relative to Brody's empirical equation determined on Holstein cattle (Brody, 1945). The difference between the two increases with body mass, reaching $23 \%$ at $650 \mathrm{~kg}$, a common weight for mature Holstein cows. This difference affects all parameters of energy requirements that are linked to the estimate of energy flux per unit SA. Calculations showed that for a cow producing $35 \mathrm{~kg}$ of milk, using Mitchell's estimate for SA would decrease LCT by about $8^{\circ} \mathrm{C}$, and reduce the rate of rise in energy requirements below the LCT by $18 \%$. At an ambient temperature of $-10^{\circ} \mathrm{C}$, the combined effects of shift in LCT and of the difference in rate of rise in energy requirements below LCT would produce a $0.4-\mathrm{Mcal} / \mathrm{d}$ increment in energy requirement by Mitchell's estimate. This low expected increase in energy requirements might explain the following statement (NRC, 2001): "For lactating cows in cold environments, the change in energy requirements is probably minimal because of the normally high heat production of cows consuming large amounts of feed." However, if Brody's estimate is used, the expected increment becomes $1.21 \mathrm{Mcal} / \mathrm{d}$, a nutritionally significant value.

At ambient temperatures above the LCT, using Mitchell's estimate for SA would increase by $5^{\circ} \mathrm{C}$ the ambient temperature at which nonevaporative skin heat loss starts decreasing. This implies a $5^{\circ} \mathrm{C}$ shift in the very onset of heat stress that requires the involvement of skin and respiratory evaporative heat loss for the maintenance of thermal homeostasis. The $23 \%$ larger estimate for total skin evaporative heat loss, the result of the larger SA assumption, leads to an underestimation of the impact of heat stress on the recruitment of respiratory heat dissipation, as well as of the tentatively resulting risks of respiratory alkalosis and reduced feed intake. It is worthwhile emphasizing that these effects 
of a larger estimate for SA are further amplified at higher milk production levels.

The equations relating body mass to SA were developed on the basis of measurements carried out on cattle 50 to $60 \mathrm{yr}$ ago. Mature dairy cattle size has since increased, owing to genetic and environmental changes. It is thus possible that the relation of body SA to body mass may have been altered, which may reduce the applicability of these equations. This possibility was examined by assuming that the relationship of body mass to heart girth or to height at withers would reflect such alterations. Third-order polynomial equations were computed for these relationships from published Holstein cattle body dimensions data collected prior to 1945 (Brody, 1945). These equations were compared to similar published equations (Heinrichs et al., 1992) computed on Holstein cattle data collected from 1987 to 1990. The equations computed from Brody's data and those reported by Heinrichs et al. (1992) produced almost identical predictions for BW from wither height or from heart girth ( $\mathrm{r}>0.999, P>0.0001)$. This supports the view that although an increase in mature body size has occurred, this has not been accompanied by a change in body proportions sufficiently large to modify the relation of body mass to body surface area.

Brody's prediction equation was based on the target species, the largest number of animals and a wide range of BW. However, Mitchell's equation, determined on medium-size sheep, is used in the ARC, NRC, and CNCPS models for estimating cold and heat effects on the energy requirements of cattle.

Taken as a whole, the results of this analysis indicate that extrapolating from one species to another for predicting SA, or extrapolating beyond the range of data from which the prediction of SA was calculated, has significant consequences. Brody's equation seems preferable for estimating the SA of Holstein cattle since it was experimentally determined on a large number of Holstein animals of different ages and weights. Using the latter equation would provide better estimates of the energy requirement in the cold and of needs for heat stress relief.

\section{ACKNOWLEDGMENT}

The permission given by the Scottish Agricultural College to use the model of thermal balance for cattle published by McGovern and Bruce (2000) for research purposes and the assistance of R. R. McGovern in clarifying matters related to this model are gratefully acknowledged.

\section{REFERENCES}

ARC. 1980. Pages 102-103 in The Nutrient Requirements of Ruminant Livestock. Commonwealth Agricultural Bureaux, Nosworthy Way, Wallingford, Oxon, U.K

Berman, A. 1971. Thermoregulation in intensively lactating cows in near natural conditions. J. Physiol. (London) 251:477-489.

Blaxter, K. L. 1967. Pages 116-146 in The Energy Metabolism of Ruminants. Hutchinson Scientific and Technical Publ., London, U.K.

Blaxter, K. L., and F. W. Wainman. 1961. Environmental temperature and the energy metabolism and heat emission of steers. J. Agric. Sci. (Camb.) 56:81-90.

Blaxter, K. L., and F. W. Wainman. 1964. The effect of increased air movement on the heat production and emission of steers. J. Agric. Sci. (Camb.) 62:207-214.

Brody, S. 1945. Pages 354-403 in Bioenergetics and Growth with Special Reference to the Energetic Efficiency Complex in Domestic Animals. Reinhold Publ., New York.

Fox, D. G., T. P. Tylutki, M. E. Van Amburgh, L. E. Chase, A. N. Pell, T. R. Overton, L. O. Tedeschi, C. N. Rasmussen, and V. M. Durbal. 2000. The net carbohydrate and protein system for evaluating herd nutrition and nutrient excretion: Model documentation. Mimeo 213. Cornell Univ. Anim. Sci. Dept., Ithaca, NY.

Fox, D. G., and T. P. Tylutki. 1998. Accounting for the effects of environment on the nutrient requirements of dairy cattle. J. Dairy Sci. 81:3085-3095.

Gebremehdin, K. G., and B. Wu. 2001. A model of evaporative cooling of wet skin surface and fur layer. J. Thermal Biol. 26:537-545.

Graham, McC. N., F. W. Wainman, K. L. Blaxter, and D. G. Armstrong. 1959. Environmental temperature, energy metabolism and heat regulation in sheep. I. Energy metabolism in closely clipped sheep. J. Agric. Sci. 52:13-24.

Heinrichs, A. J., G. W. Rogers, and J. B. Cooper. 1992. Predicting body weight and wither height in Holstein cattle using body measurements. J. Dairy Sci. 75:3576-3581.

Johnson, H. D., A. C. Ragsdale, J. D. Sikes, J. I. Kennedy, E. B. O'Bannon, and D. Hartman. 1961. Environmental Physiology and Shelter Engineering LVII. Surface Area Determinations of Beef and Dairy Calves during Growth at $50^{\circ} \mathrm{F}$ and $80^{\circ} \mathrm{F}$ Environmental Temperatures. Missouri Agric. Exp. Stn. Res. Bull. 770.

Kleiber, M. 1961. Pages 179-194 in The Fire of Life, an Introduction to Animal Energetics. Wiley \& Sons, New York, NY.

Lusk, G. 1928. Pages 122-123 in The Elements of the Science of Nutrition. 4th ed. Academic Press, New York.

McGovern, R. R., and J. M. Bruce. 2000. A model of the thermal balance for cattle in hot conditions. J. Agric. Eng. Res. 77:81-92.

McLean, J. A., W. T. Whitmore, B. A. Young, and R. Weingardt. 1984 Body heat storage, metabolism, and respiration of cows abruptly exposed and acclimatized to cold and $18^{\circ} \mathrm{C}$ environments. Can. J. Anim. Sci. 64:641-653.

Mitchell, H. H. 1962. Pages 32-41 in Comparative Nutrition of Man and Domestic Animals. Academic Press, New York.

Mitchell, H. H. 1928. Check formulas for surface area of sheep. Pages 155-158 in A Year's Progress in Solving Farm Problems in Illinois. Ann. Rep. Illinois Agric. Exp. Stn., Urbana.

NRC. 1981. Pages 66-67 in Effect of Environment on Nutrient Requirements of Domestic Animals. Natl. Acad. Sci., Washington, DC.

NRC. 1996. Pages 8-10 in Nutrient Requirements of Beef Cattle. 7th rev. ed. Natl. Acad. Sci., Washington, DC.

NRC. 2001. Pages 318-319 in Nutrient Requirements of Dairy Cattle. 7 th rev. ed. Natl. Acad. Sci., Washington, DC.

Stevens, D. C. 1981. A model of respiratory vapor loss in Holstein dairy cattle. Trans. Am. Soc. Agr. Eng. 24:151-153.

Turnpenny, J. R., A. J. McArthur, J. A. Clark, and C. M. Wathes. 2000. Thermal balance of livestock. 1. A parsimonious model. Agric. Forest Meteor. 101:15-27.

Young, B. A. 1975. Temperature-induced changes in metabolism and body weight of cattle (Bos Taurus). Can. J. Physiol. Pharmacol. 53:947-953.

Webster, A. J. F., J. Chlumecky, and B. A. Young. 1970. Effects of cold environments on the energy exchanges of young beef cattle. Can. J. Anim. Sci. 50:89-100. 